Investigaciones Fenomenológicas, vol. Monográfico 4/I (2013): Razón y vida, 331-349. e-ISSN: $1885-1088$

\title{
Heretical Dimensions of Self Responsibility BY Jan PATOČKa
}

\section{DIMENSIONES HERÉTICAS DE LA AUTORRESPONSABILIDAD EN JAN PATOČKa}

\author{
Laura Tusa Ilea \\ Romanian Phenomenological Society /Centre for Interdisciplinary Studies \\ in Society and Culture at Concordia University, Montreal, Canada \\ airarle@yahoo.com
}

\begin{abstract}
Jan Patočka's account of responsibility, as developed in Heretical Essays in the Philosophy of History, is configured through the philosopher's entire model of history, seen less as a scale of progress, but rather as a rupture. Responsibility is possible only for a very specific form of humanity, centered on history, problematicity and self-disclosure. This type of historic humanity is in profound contrast with the prehistoric one, focused on "daimonic participation." Responsibility involves the passage from prehistory to history. Despite the fact that it requires an intense "discipline of the soul," the passage to responsibility cannot become pure and transparent, which in turn means that history is repeatedly threatened by falling back into prehistory. The positive involved in this assumption is that responsibility is not taken for granted; it is not a matter of following metaphysical principles, but rather a matter of a practical, "heretical" decision of embracing history, with its shaken problematicity, and of resisting the temptation of prehistory.
\end{abstract}

Key Words: Philosophy of History, Phenomenology, Genealogy of Responsibility, Self.

\begin{abstract}
Resumen: La comprensión de Jan Patočka de la responsabilidad, tal como se desarrolladen Ensayos eréticos de filosofía de la Historia, viene configurada por el modelo completo de Historia, vista más como una ruptura que como una escala de progreso. La responsabilidad es posible sólo para una forma muy concreta de humanidad, centrada en la historia, la problematicidad y el autodescubrimiento. Este tipo de humanidad histórica se halla en profundo contraste con el tipo prehistórico, focalizado sobre la "participación demónica". La responsabilidad implica el tránsito de la prehistoria a la historia. Pese a requerir una intensa "disciplina del alma", el tránsito a la responsabilidad no puede tornarse puro y transparente, lo que a su vez significa que la historia está constantemente amenzada por una recaída en la prehistoria. El lado positivo que esta asunción envuelve es que la responsabilidad no se da por garantizada; no es una cuestión de seguir principios metafísicos, sino más bien cuestión de una decisión práctica, "herética", de abrazar la historia, con su problematicidad conmovida, y de resistir la tentación de la prehistoria.
\end{abstract}

Palabras clave: Filosofía de la historia, fenomenología, genealogía de la responsabilidad, yo.

One of the distinguishing features of a philosophical career is to be touched by a moment of pessimism, by the acknowledgment that the entire mold in 
which it articulates "reality" is fragile, and enables only a restricted perspective on a situation that remains intangible in its entirety. Despite continuous efforts to formulate the "principle of reality", philosopher's life is confronted with moments when the complex game of history seems to exceed his understanding, as well as his capacity to judge.

Heretical Essays in the Philosophy of History by Jan Patočka ${ }^{1}$ seems to be such a moment of pessimism, but at the same time it also represents the humble and uncompromising hope that the humanity of homo humanus is more resistant to the apparently innumerable dead ends posed by contemporary technologic era. It starts from the presupposition-present also in different other texts written by the Czech philosopher-that the twentieth century and the beginning of the twenty-first century have exhausted the most audacious nihilistic possibilities ${ }^{2}$.

As a first step in my analysis, I will raise the following question: Whom should we blame for the disasters that shaped the twentieth century? Metaphysics with its constant aspirations that lead to sacrifices in the name of a transcendental idea? Or should we simply say that European history was a long odyssey of cruelty, especially when it started the saga of an increasing expanding power, as of the sixteenth century?

The consequence of such assumptions would be that there is no transcendental order that could impose its strategies. Moreover, since humanistic dogmas seem to become obsolete, there would be no underlying human virtues that could impose a higher responsibility or different behavior dogmas. Consequently, the notion of responsibility becomes problematic: in the name of what principle could we proclaim human rights, responsibility to the others and to the world, to environment and to the generations to come? What are the notions involved in discussing self-responsibility and how can we restore their meaning?

These are questions I will answer in this article, by focusing on Patočka's model of history as a specific type of human quest. It is shaped by a precise moment that originated in early Greek times, when the debate with death was

\footnotetext{
1 Jan Patočka, Heretical Essays in the Philosophy of History, transl. Erazim Kohák, (Chicago and La Salle, Illinois: Open Court, 1996).

2 Jan Patočka, "L'homme spirituel et l'intellectuel" in Liberté et sacrifice, transl. Erika Abrams (Grenoble: Jerôme Millon, 1993), 254, describes three forms of nihilism as follows: the joyful, creative nihilism; the nihilism that surrendered to an objective power; and the perplex nihilism, suffering from a form of internal paralysis.
} 
confronted directly, instead of being approached through ancient wisdom, myths, and consolation rites. This inaugural moment occurred during the time of Socrates, who validated a philosophic dogma by his courage of defying death-and eventually through his own death. This was the moment when philosophical arguments regarding fundamental notions such as a life worth living, beauty, justice, immortality, rules and state were debated in agora. For Patočka, Greek polis embodies the simultaneous birth of philosophy, of politics and of history; it represents the most eloquent incarnation of the passage from prehistory to history, the moment when humans were finally placed at the core of the Greek worldview, with all disadvantages involved.

Even if Patočka's account of "the birth of history" on the model of the Greek polis may seem naïve, there is an important aspect that we should still consider: the Czech philosopher places problematicity at the very core of history. Problematicity is the condition sine qua non of a form of humanity that strongly embraces history-a humanity that considers life in freedom as superior to mere life.

Being the main attribute of the "historic condition" problematicity represents at the same time the intrinsic initiator of countless quests that eventually resulted in different forms of hybris-science, technology, exploration of outer worlds, psychoanalysis, bioscience. In other words, the multifarious perspectives that Patočka ascribes to the twentieth century are already grounded in the very dawn of Western civilization; they originate in the inception of its history, through a specific determinant: problematicity.

Further on, I will investigate Patočka's understanding of the passage from prehistory to history, as well as his view on the reasons why other important civilizations would not have embraced this specific type of "historical" quest.

\section{PREHISTORY-HISTORY}

When reviewing Heretical Essays in the Philosophy of History, Aviezer Tucker accused Jan Patočka of inconsistencies, attributed to the philosopher's bitterness of living the end of his life under a merciless Communist regime. The author claims that, "after the reasonable start" of tracing back history's beginning to the simultaneous birth of the Greek polis, of philosophy and of politics, 
Patočka reached some unbelievable, at best naïve, and at worst proto-Fascist, conclusions about history that are inconsistent with his interpretation of the polis and the ethical system of the founder of the Charter 77 movement of human rights in Czechoslovakia. $^{3}$

A second claim made by Aviezer Tucker against Patočka concerns his argument that Hellenic and Roman Empires had fallen because "they failed to convince their citizens that they were just". According to him, Patočka presented the fall of the polis, the Hellenic world and the Roman Empire, "as a public relations problem". The Czech philosopher would have claimed that the European Middle Ages represented the zenith of European history, focused on "care for the soul", truth, justice, and authenticity. Tucker's boldest affirmation is that "Patočka regarded war as the greatest enterprise of technological civilization, total mobilization"4.

There are many occurrences in Patočka's Heretical Essays in the Philosophy of History that work against this kind of affirmations. I believe that Tucker is misled by Patočka's dealing with "ambiguous" notions such as war, phenomenology of darkness, and conversion, implied by the passage from "orgiastic" to responsibility. My intention is to further clarify these notions, in order to explain the Czech philosopher's ideas about history, as well as his concept of responsibility.

Patočka's demonstrations assume indeed that European history is mobilized around the concepts of the soul, of justice and of authenticity. Generally speaking, he refers to a very specific historical type of humanity centered on problematicity, on finitude as problem, on a "disintegrated conscience". History as such is incompatible with the prehistoric era, precisely because it represents a different type of approach, based on the full conscience of death instead of rituals, on the acceptation of a problematic condition and on the attempt to find a trace of everlastingness through political action, philosophy, and poetry, instead of transferring the weight of decision to gods-the only immortal beings in an universe prone to decay. History does not overlap with the entire trajectory of the humanity. It is a rupture, a differentiation.

\footnotetext{
${ }^{3}$ Aviezer Tucker, "Reviewed work: Essais Hérétiques sur la Philosophie de L'Histoire by Jan Patočka" in History and Theory, Vol. 31, No. 3 (Middletown, Connecticut: Blackwell Publishing for Wesleyan University, Oct. 1992), 356.

${ }^{4}$ Ibid., 358.
} 
My argument is based precisely on this distinction: Patočka does not identify the beginning of history with the first written proof of human civilized life, but with the very moment when the conscience of problematicity arises, when life becomes unsheltered. Whereas prehistorical life is characterized by "acceptance, transmission, preservation, securing of life" ${ }^{\prime 5}$, recorded in annals, the historical phase involves an unsheltered life led "in active tension, one of extreme risk and upward striving" ${ }^{\prime 6}$.

What is disquieting about this statement is that Patočka considers even sophisticated civilizations such as the Near East, Egypt and ancient China as prehistorical, "great households" aiming at the simple "preservation of the lifestyle of prehistorical humanity" (28). He does not intend to downgrade this type of civilizations by rejecting them to a phase that completely lacks complexity. His argument refers instead to the fact that prehistory and history are differently articulated as a whole. Their worldviews are not compatible. Whereas prehistoric civilizations are in full harmony with the surrounding world, the distinctive feature of a problematic, historic society is its detachment from nature and from simplicity. On the other hand, Patočka fears that contemporary humanity may no longer be willing to embrace history with all its array of inconveniences. On the contrary, it rather wants to adopt a more serene form of life, strongly connected with the surrounding world. This would not mean recession, but a shift in the way humanity conceives itself.

Moreover, in order to understand what Patočka has in mind when he alludes to the abyss opened between prehistoric and historic civilizations, we should mention that he conceives existence as determined by three movements: acceptance, defense, truth ${ }^{7}$. These three movements are paralleled with the Aristotelian three souls (vegetative, animate and rational), as well as with Hannah Arendt's three movements of life: labor, work and action. From all three, only the last one is fully incarnating the historic "human condition," with its highs and lows, with its greatness as well as with its risks.

\footnotetext{
${ }^{5}$ Patočka, Heretical Essays, 28.

${ }^{6}$ Ibid., 36.

7 See Patočka, Heretical Essays, 28-40, as well as "The 'Natural' World and Phenomenology," in Erazim Kohák, Jan Patočka: Philosophy and Selected Writings (Chicago\&London: The University of Chicago Press, 1989), 239-273, "Care and the Three Movements of Human Life," and "The Three Movements of Human Life," in Jan Patočka, Body, Community, Language, World (Chicago and La Salle, Illinois: Open Court, 1998), 143-153 and 153-163.
} 
Acceptance is characterized in Patočka's view by mechanical adaptation, by the submission to the ever-recurring rhythm of nature. This is the main feature of animal laborans. Defense is characterized by a rhythmical alternation of burden and relief, of oppression and alleviation. It consists in an exchange between acceptance and ecstasy. Ecstasy is described as the "increasingly intense abandon that lets us touch upon the realm of the undifferentiated in ecstasy and participate in it as in the bliss of being ${ }^{\prime 8}$.

The quest for truth implies a distance and a reaction. But against what? What differentiates the quest for truth, the care for the soul and ideals of authenticity and justice, made possible by the historic paradigm, from the absolute order of the purely natural rhythm of "divine households," characterized by a cosmo-ontological metaphor without barrier between the human society and the universe? ${ }^{9}$.

This cosmo-ontological metaphor involves the idea that there is no difference between what is and 'being,' between phenomena and their manifestation. Both dimensions converge on a single plan. Experience and symbolic metaphor belong to a similar level of reality as the everyday burden and the honoring of the ancestors. Life and death succeed each other in an unfathomable, unquestioned rhythm. "Humans before history do not differentiate between the night as fact of experience and night as darkness out of which the lightning of being strikes" $^{10}$. For them, "Being shares with beings the same region of one and the same world in which everything is simultaneously manifested and concealed" (35).

On the contrary, history constitutes a rupture. Patočka characterizes history as "a distancing from and a reaction against the period of prehistory", "a rising above the level of the prehistorical, an attempt at a renewal and resurgence of life" (36). In other words, history could be equated with a propaedeutic for a different conception of life's meaning.

\footnotetext{
8 Patočka, Heretical Essays, 32.

${ }^{9}$ Ibid., p. 35: "The will to permanence is essentially sacral and ritualistic, having to do with a fundamental characteristic of prehistoric truth-the cosmic-ontological metaphor."

${ }^{10}$ Ibid. 32.
} 


\section{RESPONSIBILITY AND HISTORY}

In Patočka's view, one cannot talk about responsibility without fully assuming the historic condition. However, when analyzing Patočka's notion of responsibility, Jacques Derrida shifts the discussion towards the religious context, by clearly distinguishing between daimonic participation-in which the self accomplishes its role only as part of community-and the religion of responsibilitywhich involves the genealogy of a free subject. Derrida's thesis concerning Jan Patočka's Heretical Essays in the Philosophy of History underlines that "one can speak of religion once the demonic secret, and the orgiastic sacred, have been surpassed"11.

In Derrida's view, there are two different types of religion. Firstly, the demonic, "orgiastic" type of religion, which emphasizes participation, by putting forward notions in which the whole community believes. Secondly, the religion of responsibility involves a different configuration of the self, focused on an apparently "absurd" decision, as in Kierkegaard's Fear and Trembling, on a "heretic" dislodging that overcomes ancestor's knowledge and the participatory forms of truth.

The concept of daimon is used by Jan Patočka when referring to the multilayered dimension of the self. The self would be easily understood if it were only a rational part of a greater responsibility project, if it would not involve any kind of boundary-crossing. But daimon constitutes the original metaphor of the self-being inherently connected to and at the same time radically distanced from us. Daimon is invisible to us and visible to the others. Truth about the self is translated in prehistorical times through daimonic power, pertaining to others. We do not have complete access to our truth because we are not confronted with the decision of responsibility. This is the reason why in prehistoric times our self belongs to the others, as revelatory daimon.

Daimon is invisible for two reasons: firstly, because it configures a space of irresponsibility, a space of crossing borders between the human, the animal and the divine. It shares many affinities with what Patočka calls "undifferentiated night", where "one does not yet hear the call to explain oneself, one's actions, one's thoughts, to respond to the other and answer for oneself before the oth-

\footnotetext{
11 Jacques Derrida, "Secrets of European Responsibility", in The Gift of Death \& Literature in Secret, transl. David Wills (Chicago\&London: The University of Chicago Press, 1995), 4.
} 
$\mathrm{er}^{\prime \prime 12}$. Secondly, in prehistoric times one's actions cannot configure completely a personality without gaining power from the community. I am not fully a master of myself and of my acts. The way I appear to others diverges in most cases from my personal image-from how I intend to act and to react. Daimonic participation seems to be separated by a profound gap from the responsibility project, characterizing the historic communities.

Under these conditions, how can the orgiastic participation of prehistoric civilizations accomplish the passage towards a project of responsibility? Moreover, how can such a project become institutionalized, when, according to the main Christian dogmatic thesis, responsibility is a matter of facing mysterium tremendum?

Derrida advances two theses concerning the project of responsibility: first of all, he points out that in the tripartite European project analyzed by Jan Patočka (Greek polis, Roman Empire, Christian religion), the Czech philosopher emphasizes the latter. Secondly, in his view, Patočka's description of Europe attempts to modify the European project by underlining the exceeding responsibility of the mysterium tremendum. Facing such an overwhelming dialectical counterpart-the transcendence of the Other-, responsibility remains in itself a secret. Compared to the prehistoric secrecy, based on the incomprehensible power of the divine, the secret of responsibility relies on a configuration of the self stemming from practical decisions, which defy knowledge and norms and which are heretic to a certain degree. The self is shaped through these face-toface processes (for example Socrates' trial of death, Abraham's trial of faith, Kierkegaard's repetition, Patočka's problematic historic condition). In Derrida's view (and this is his second argument):

Religion exists once the secret of the sacred, orgiastic, or demonic mystery has been integrated, subjected to the sphere of responsibility... Religion (history) is responsibility or it is nothing at all. Its history derives its sense entirely from the idea of a passage to responsibility. ${ }^{13}$

This passage to responsibility is primarily an individual act (see Abraham's conversion in Kierkegaard's Fear and Trembling). Originally, it is not altogether

${ }^{12}$ Ibid., 5.
${ }^{13}$ Ibid. 
a rational act, a matter of knowledge of the good as it was in Platonism. In order to accomplish the passage from an individual to a collective responsibility, there is the need of a coherent rational project. This passage is a matter of individual "unworldly conversions", - like love and the encountering of deathwhich become collective "worldly occurrences"-for instance respect, civil rights, and religious regulations. The bridge between the individual act and the collective responsibility implies a rational transformation. At the core of the responsibility project, there is an individual "secret", a personal decision to obey something that one does not fully encompass. The passage to rationality goes through an exceeding experience of assuming the responsibility.

Even if Patočka refers frequently to politics, philosophy and history by analyzing the notion of responsibility, Derrida insists on the fact that "the history of responsibility is tied to the history of religion" and that there is no other way out of this. Even though today responsibility may be founded on civil rights, on a specific type of humanistic understanding, in Derrida's view, the propaedeutic passes through a religious conversion, and especially through absolute decisions that involve departing from knowledge or given norms.

In my opinion, when discussing Patočka's role of conversion, Derrida insists too much on the religious aspect. I would rather emphasize the phenomenological concept of everydayness that is "converted" through the decision of responsibility. In order to understand Patočka's account of historic responsibility, we should consequently focus on the phenomenological background of the concept of everydayness. In Patočka's view, everydayness has not only the neutral Heideggerian accents; it is not only a pure phenomenological description of the most elementary traits of a being-in-the-world, but it belongs to a level of experience that remains fully absorbed in the process of life preservation, life multiplication, securing of the private household. As a reaction to the pressure exercised by daily life conditions, the human being has always tried to escape the circle of everydayness, either through daimonic forms of participation or through ethical decisions that traced the path towards responsibility. All human achievements are indebted to an attempt to overcome everydayness, mere life, life preservation.

In other words, Patočka's conception regarding the passage from prehistory to history is based on two ways of overcoming the problems of everydayness. a) The first one is achieved through the secrecy of the orgiastic, the sacred as 
enthusiasm or fervor for fusion-Eleusis mysteries, for example. b) The second path is achieved through responsibility. It is a completely different approach than the first one because it engages a genealogy of the self that is no longer a matter of acceptance of rules, rituals and worldviews; it is no longer an immersion into a sheltered form of life. The self is shaped through an unsheltered form of confronting death, by assuming a problematic condition rendered by the fact that man acknowledges his finitude and his capacity to convey an answer to it.

Moreover, the genealogy of responsibility involves a relationship to death, based not on its integration into a perennial rhythm of ever-recurring birth and rebirth, but on dramatical confrontation with death. The gift of death is the main accomplishment of the conversion from orgiastic secrecy to responsibility. "A history of secrecy as history of responsibility is tied to a culture of death" (12).

The term "culture of death" may seem misleading. It is not necessarily tied to Christian religion. Patočka places its first roots in Socrates' trial of death, which proved, this time in a philosophical way, Socrates' belief in the immortality of the soul. But it is also constituted by contemporary attempts toward a "hermeneutics of facticity", of everydayness: Martin Heidegger (Being and Time $)^{14}$, Paul Ricœur (Fallible Man) ${ }^{15}$, Hans Jonas (The Imperative of Responsibility $)^{16}$; they all have in common the assumption of finitude, of frailty and of the human mortal condition.

Being an intense discipline connected to a culture of death, this project of responsibility represents at the same time the achievement of a dimension beyond death, immortality. It constitutes the birth of a new conscience that is for the first time able to look death in the face, and through this process, conscience attains a new freedom. The orgiastic becomes responsibility through an intense discipline of the soul as an attentive anticipation of death. This anticipation - called by most philosophers care, concern, or solicitude- manifests as a sort of thaumaturgy, an art healing for a life threatened by decadence.

\footnotetext{
${ }^{14}$ Martin Heidegger, Being and Time, transl. by John Macquarrie and Edward Robinson (London: SCM Press, 1962); re-translated by Joan Stambaugh (Albany: State University of New York Press, 1996).

${ }_{15}$ Paul Ricœur, Fallible Man, transl. Charles A. Kelbley, with an introduction by Walter J. Lowe, (New York: Fordham University Press, 1986).

${ }^{16}$ Hans Jonas, The Imperative of Responsibility: In Search of Ethics for the Technological Age (transl. of Das Prinzip Verantwortung) trans. Hans Jonas and David Herr (1979). (University of Chicago Press, 1984).
} 
We should keep in mind that, in Patočka's view, such history implies understanding the secret relations between three mysteries-orgiastic, Platonic, Christian-and two conversions-orgiastic-Platonic, Platonic-Christian. We could say that responsibility means inserting oneself into a history that becomes ripe for its project, but on the other hand, it also implies a practical decision, breaking with given norms. The genealogy of responsibility is connected to heresyin the sense of a practical decision that goes beyond any theoretical background determination. It overlaps with the genealogy of the self; in this confrontation between certainty and uncertainty, the risk involved is precisely what gives shape to the self.

To summarize, Derrida's interpretation of Patočka tackles responsibility as tied to three different factors: first of all, to practical decisions that involve breaking with knowledge or given norms; to faith, which manifests as a "venture into absolute risk, beyond knowledge and certainty"; and finally, it is connected to the gift of death, in its relation with the transcendence of the other.

\section{Polemos as A WAy of REStORing MEANing}

The passage from prehistory to history, in other words from orgiastic to responsibility, involves an important additional feature, which is maybe the most obscure notion in Patočka's philosophy of history: namely polemos, understood as triumph over death. Responsibility is subject to a perpetual struggle because it implies that one is placed at the limit of human possibilities, facing decadence, death, and nihilism. There is no responsibility when there is no threat of falling back into the inhuman-into "undifferentiated night".

This disquieting premise, for which he was accused of being reactionary, stands at the heart of Patočka's thought. Paul Ricœur considers his essay "Wars of the Twentieth Century and the Twentieth Century as War" to be a "strange, frankly shocking" essay, involving "a paradoxical phenomenology of darkness"17, a fragile contract between night and day.

In this context, Patočka's discourse seems misleading. However, it can be traced back to Heraclitus' theory of unity of opposites. Patočka's argumentation could be misleading because it talks about "war as a further experience of the

\footnotetext{
${ }^{17}$ Paul Ricœur, "Preface to the French Edition of Jan Patočka's Heretical Essays", in Heretical Essays, viii.
} 
gift of death ${ }^{18}$, as if he praised war as a modality to restore meaning. As if, without facing the concrete danger of a life-destroying situation, meaning no longer survived, veiled by either the exceeding indifference of consumerism or by the non-reflexive overpowering of technology. In other words, restoring meaning would be mostly possible under paradoxical, threatening conditions. Under these circumstances, war seems to be the most authentic escape when trying to overcome the inauthenticity of everydayness. But Patočka affirms that it manifests nothing else than a violent discharge of the orgiastic, which in prehistoric times signified the sacred instinct. In this ambiguity posed by war resides its malevolent and attractive power. Undoubtedly, through facing limit situations, through its encountering of death as a "common" event, war has nothing to do with the placidity and the banality of everydayness. In times devoid of any discipline of the soul, there are not many means available for overcoming the profound boredom of everydayness.

The message I want to convey through this text is that, in Patočka's view, war seems to be the solution for a form of humanity that in principle has not yet overcome a prehistoric type of participation, despite the fact that it lives under historic conditions. In other words, it has not yet accomplished the passage from prehistory to history.

If in prehistoric times the sacred is directly connected to orgiastic ritualsthat sometimes lead to temporary destitution of the secular order-, in historic times this "sacred model" is replaced by the responsibility project, which involves in its turn (see above page 14) the tripartite dimension of "heretical" decisions-breaking with knowledge or given norms, faith and the gift of death.

Tucker's analyses seem correct in this respect. I will quote him extensively, because I think that his debate highlights the illusion that life-threatening situations unveil an authentic part of being.

The experience of self-sacrifice in war certainly liberates those who experience it from the concerns of everyday, from the mediocrity of production and reproduction. But this liberation is not necessarily an improvement on mediocrity; sometimes, and perhaps most of the time, it begets a deterioration, a dehumanization... Most veterans, from Sulla's to contemporary Vietnam vets, or Russian veterans of the Afghanistan war, or Israeli veterans of the Lebanon war, do not gain much from

${ }^{18}$ Derrida, The Gift of Death, 19. 
losing the ordered life of production, consumption, and reproduction, because they have within them nothing to guide them out of the apocalypse. Jaspers was wrong in thinking that life-threatening situations alter people. It seems more plausible that such situations bring out personality traits that are usually hidden below the surface. War brings out the sadists and the saints, the dehumanizing and the human, but mostly in the life of ordinary people it begets confusion. ${ }^{19}$

His conclusion envisions the saga of consumerism as opposed to ideals of transcendence, which permeate European civilization. Consumerism is understood as absolving the human quest from the need to find a dimension "beyond the self". It is also conceived as "suburbanization", focused only on suburban dreams, renouncing any false transcendence, as if it were the scapegoat for a whole history of human violence and cruelty.

However, in my opinion, "suburban dreams", immersed in a complete lack of transcendence, succumb to a disease sometimes even more disquieting than the transcendental quest: the odyssey of profound boredom. Boredom represents under these circumstances less a mood ${ }^{20}$, but rather the ontological condition of a form of humanity that subordinates life to everydayness and anonymity.

\section{CAN THE RESPONSIBILITY PROJECT BECOME PURE AND TRANSPARENT?}

Boredom as an ontological condition is not harmless. The twentieth century is the proof that the "demonic peak" (Patočka), as a consequence of boredom and relativism of all values, can go hand in hand with the greatest sobriety and rationality. In Patočka's view, at the end of the historic saga, humanity seems to return to where it began: to the rejection of everything that can problematize the everydayness, the here and now. Under these conditions, every form of overcoming the everydayness is seen in its potential fallacy, as it was proven by the turbulent development of history. The difference from the inception of history lies in the fact that, instead of pure subsistence, boredom creates its own substitutes of transcendence, its own disguises of meaning.

\footnotetext{
19 Tucker, "Reviewed work: Essais Hérétiques sur la Philosophie de L'Histoire by Jan Patočka", 361.

${ }^{20} \mathrm{See}$ also in this respect Martin Heidegger, The Fundamental Concepts of Metaphysics. World, Finitude, Solitude, transl. William McNeill and Nicholas Walker (Bloomington and Indianapolis: Indiana University Press, 1995), 78-169.
} 
Maybe human beings cannot live basked in relative meaning. Relative meaning could be only an illusory substitute to transcendence, threatened by a continuous 'falling back' into the orgiastic-understood as a way to elude the responsibility project. Instead of a self-configuration that occurs as a triumph over death, the orgiastic re-emerges in the form of a participatory sacredness. The decline into the orgiastic is always possible because, by lacking the complex configuration of the responsibility frame- practical decisions, polemos as triumph over death, hairesis as courageous assuming of a problematic condition-, the only way to overcome the "banality" of everydayness remains a collective outburst of energy. Patočka gives several examples of this return of the orgiastic, by saying that every revolution contains elements of the sacred, in the forms of the Fatherland, of Liberty and of Reason. The rejection of the complex constellation in which the responsibility project was born leads to alienating

humans from themselves, depriving them of dwelling in the world, submerging them in the everyday alternative which is not so much toil as boredom, or in cheap substitutes and ultimately in orgiastic brutality. ${ }^{21}$

In summary: on the one hand, every dramatic change in history is threatened by falling back into the orgiastic - the return of the sacred, of prehistory. On the other hand, in order for the orgiastic to become a philosophical-political program, it needs to be fully integrated in the new project of freedom and responsibility based on the structure of a well-configured self. The best scenario would be that the orgiastic be entirely forgotten. Yet, its temptation cannot be fully removed; it can be only disciplined and made subservient. In other words, the prehistoric configuration emerges in the most fragile moments of history, namely when revolutions, wars and abrupt changes occur. According to Patočka, it is very likely that the responsibility project could not become pure and transparent. This conclusion has obvious Nietzschean accents.

Whereas in the Heideggerian equation authenticity-care, the element of a tamed daimon (war, violence, devastation) does not appear, in Patočka's argument it is fully developed. Consequently, according to Derrida, Patočka's genealogy is more Nietzschean than Husserlian and Heideggerian. The

${ }^{21}$ Patočka, Heretical Essays, 117. 
Heideggerian existential analysis becomes obsolete in Patočka's program if the project of self-responsibility cannot become pure and transparent. The political lesson involved in such conclusion confirms that "every thought revolution bears witness to a return of the sacred in the form of enthusiasm or fervor (presence of the gods within us, nadir of devastation)" ${ }^{\prime 22}$.

Derrida's conclusion regarding Patočka's diagnosis on the genealogy of responsibility refers once again to its heretical character: responsibility is on the one hand subject to the objectivity of knowledge. But on the other hand it is also subject to a practical decision that goes beyond any theoretical or thematic determination. As a consequence, it is tied to heresy, hairesis as decision, choice, inclination.

\section{THE RELEVANCE OF PATOČKA'S DIAGNOSIS FOR THE CONTEMPORARY WORLD}

In our case, as witnesses to a "post-European" civilization ${ }^{23}$, the decision of responsibility reveals a dilemma: it is not only a matter of whether there are absolute or liberal principles in the name of which responsibility could be justified (reason, nature, God), but whether contemporary humanity is still willing to embrace history as such. Patočka's answer is very clear in this respect. He is concerned that humankind is no longer willing to embrace history with its intrinsic tension and its shaken problematic.

According to him, the situation seems to have no escape:

Modern civilization suffers not only from its own flows and myopia but also from the failure to resolve the entire problem of history. Yet the problem of history may not be resolved, it must be preserved as a problem. Today the danger is that knowing so many particulars, we are losing the ability to see the questions and that which is their foundation. ${ }^{24}$

\footnotetext{
22 Derrida, The Gift of Death, 23.

${ }^{23}$ According to Patočka, the European project was entirely dissolute following the "two suicides" of the twentieth century: the two World Wars. There are also other voices that consider the "post-European" era to be a consequence of the "crisis" already announced by Husserl at the beginning of the twentieth century. See in this respect: E. Husserl, The Crisis of European Sciences and Transcendental Philosophy (1936/54), transl. David Carr (Evanston: Northwestern University Press, 1970), Jan Patočka, L'Europe après l'Europe, transl. Erika Abrams, (Verdier: Lagrasse, 2007), Jacques Derrida, L'autre Cap (Paris: Les Editions de Minuit, 1991), Marc Crépon, Altérités de l'Europe, (Paris: Galilée, 2006).

24 Patočka, Heretical Essays, 118.
} 
The concept of history as insolvable means that we should remain "at the limit of human possibilities" by acknowledging that the responsibility project cannot be given once and for all. It continually threatens to fall back into the inauthentic, the violent and the orgiastic return of the sacred. Self-sacrifice is not enough to enable the restoration of authentic human nature. On the contrary, without consistent practice and self-discipline, self-sacrifice can lead to confusion and violent ideologies.

In order to follow a possible path towards the restoration of the integral humanity, those willing to undertake it must be prepared: self-sacrifice means for Patočka "the overcoming of the technical understanding of being" ${ }^{25}$. Under general conditions, sacrifice means obligation: we sacrifice something inferior, in order to gain something superior. Patočka insists on a Christian paradigm, which does not place the divine force under any obligation. Christianity frames the divine precisely as rooted in the radicalism of the sacrifice.

The force of sacrifice confers power and understanding to our inner relationship to truth. It is capable of reshaping the content of the world we live in. While Patočka banks on this force of transformation, he is on the other hand aware of the fact that it is kept in a very fragile balance: the orgiastic returns in hidden and distorted forms in the midst of the responsibility project, precisely because history is not a frozen concept, a stage on the scale of progress. On the contrary, history shapes a problematic configuration of humankind, based on polemos, on courageous defying of death, on assuming responsibility. All these dimensions seem to be of no worth in difficult times. Thus the temptation of returning to non-responsibility, to non-ethics, to pervasive voices of hidden sacredness. The sacrifice of maintaining oneself at the

dark limits of human possibilities is the characteristic experience of our time and of the time just passed, an experience which might lead to a transformation of the way we understand both life and the world-a transformation capable of bringing our outwarldly rich yet essentially impoverished age to face itself, free of romantic underestimation, and thereby to surpass it. ${ }^{26}$

\footnotetext{
25 Jan Patočka, "The Dangers of Technicization in Science according to E. Husserl and the Essence of Technology as Danger according to M. Heidegger," in Erazim Kohák, Jan Patočka: Philosophy and Selected Writings (Chicago\&London: The University of Chicago Press, 1989), 337.

${ }^{26}$ Ibid., 339.
} 
As a consequence, when Patočka addresses the notions of darkness and night, contrary to what Tucker believes, he discusses on the one hand the danger of falling back into the "undifferentiated night"; on the other hand he admits that "darkness" is not only a stage in the development of mankind, to be overcome in the name of peace. On the contrary, the philosophy of history should take into account war at its very heart; and peace only as an exception, as an island of unexpected balance.

Contrary to these apparently "orphic" sentences, Patočka's investigations do not lead to a prescription of metaphysical dogmas. In his view, metaphysics is only one of the projects through which historical humanity has embodied its quest for truth. The Czech philosopher does not suggest a return to a metaphysics that contains underlying dogmatic certainties. What he proposes is a non-dogmatic openness towards a form of transcendence that involves responsibility as "solidarity of the shaken but undaunted". His solution also evokes what he calls problematicity: an attitude which takes into account negative experiences and formulates inquiries into what generally seems obvious. Responsibility thus understood creates authentic social institutions, authentic "public relations" and a kind of philosophy that is not only repeating general metaphysical statements but trying to find roots in a problematic reality.

\section{CONCLUSION}

As argued by Jan Patočka in Heretical Essays in the Philosophy of History, there are two distinct types of humanity: the prehistoric one, centered on the dimension of the "orgiastic"; and the historic type of humanity, based on responsibility.

In order to answer the questions-how can the orgiastic participation of prehistoric civilizations accomplish the passage towards a project of responsibility and how can such a project be institutionalized-I have focused on the thesis that, based on Patočka's account of history, responsibility embodies the project of a specific form of humanity, centered on history, problematicity and disclosure of the self. The "orgiastic" becomes responsibility through an intense discipline of the soul, as an attentive anticipation of death-anticipation that manifests as a sort of thaumaturgy. 
Moreover, despite this intense discipline of the soul, the passage from "orgiastic" to responsibility can never be fully accomplished. In Jan Patočka's view, the temptation of the "orgiastic,"-of the prehistoric-occurs in the most fragile moments of history, namely when an unquestioned sacredness tends to replace the decision of responsibility. This is the reason why the responsibility project cannot become pure and transparent.

The decline into the orgiastic threatens continuously because, by lacking the complex configuration of the responsibility frame, the only way to escape the circle of everydayness seems to be by means of a collective outburst of energy. The return of "prehistory" in the midst of the responsibility project is explained by the problematic configuration of history-based on polemos, decision, responsibility-that seem to be of no worth in difficult times. Thus the temptation of returning to non-responsibility, to non-ethics, to daimonic participation.

The threat to fall back into the inauthentic, the violent and the orgiastic return of the sacred makes responsibility not only a matter of following metaphysical principles and given norms, but also a matter of practical conversion, of an ever repeated decision to resist the apparently powerful outbursts of energy that testify for a return of a violent sacredness. Responsibility means willing to embrace history, with its shaken problematicity.

\section{BIBLIOGRAPHY}

DERRIDA, Jacques. "Secrets of European Responsibility" in The Gift of Death \& Literature in Secret, transl. David Wills. Chicago \& London: The University of Chicago Press, 1995.

FINDLAY, Edward F. Caring for the Soul in a Postmodern Age. Albany: State University of New York Press, 2002.

HEIDEGGER, Martin. Being and Time, transl. by John Macquarrie and Edward Robinson. London: SCM Press, 1962; Re-translated by Joan Stambaugh. Albany: State University of New York Press, 1996.

HEIDEGGER, Martin. The Fundamental Concepts of Metaphysics. World, Finitude, Solitude, transl. William McNeill and Nicholas Walker. Bloomington and Indianapolis: Indiana University Press, 1995.

JONAS, Hans. The Imperative of Responsibility: In Search of Ethics for the Technological Age (trans. of Das Prinzip Verantwortung) transl. Hans Jonas and David Herr (1979);Chicago: University of Chicago Press, 1984.

KOHÁK, Erazim. Jan Patočka: Philosophy and Selected Writings. Chicago \& London: The University of Chicago Press, 1989. 
LOM, Petr. "East Meets West-Jan Patočka and Richard Rorty on Freedom: A Czech Philosopher Brought into Dialogue with American Postmodernism", in Political Theory, Vol. 27, No. 4 (Aug., 1999), 447-459.

PATOČKA, Jan. Body, Community, Language, World. Chicago and La Salle, Illinois: Open Court, 1998.

- Four Seminars on the Problem of Europe (Care for the Soul, Vol. 3: Collection of Essays and Notes on the Problems of the Situation of Man in the World and in History), Prague, Jan Patočka Archive, Center for Theoretical Study.

- Heretical Essays in the Philosophy of History, transl. Erazim Kohák. Chicago and La Salle, Illinois: Open Court, 1996.

- L'Europe après I'Europe, transl. by Erika Abrams. Verdier: Lagrasse, 2007.

- Plato and Europe. Stanford: Stanford University Press, 2002.

- "Care and the Three Movements of Human Life" and "The Three Movements of Human Life" in Body, Community, Language, World. Chicago and La Salle, Illinois: Open Court, 1998.

- "The Dangers of Technicization in Science according to E. Husserl and the Essence of Technology as Danger according to M. Heidegger" in Erazim Kohák, Jan Patočka: Philosophy and Selected Writings. Chicago\&London: The University of Chicago Press, 1989.

- "L'homme spirituel et I'intellectuel" in Liberté et sacrifice, transl. Erika Abrams. Grenoble: Jerôme Millon, 1993, 243-275.

- "The 'Natural' World and Phenomenology" in Erazim Kohák, Jan Patočka:Philosophy and Selected Writings. Chicago\&London: The University of Chicago Press (1989), 239-273.

RICOEUR, Paul. Fallible Man, transl. Charles A. Kelbley. New York: Fordham University Press, 1986.

TUCKER, Aviezer "Reviewed work: Essais Hérétiques sur la Philosophie de L'Histoire by Jan Patočka", in History and Theory, Vol. 31, No. 3. Middletown, Connecticut: Blackwell Publishing for Wesleyan University (Oct. 1992), 355-363. 